\title{
Biocontamination Risk of Staphylococcus aureus in Dairy Manufacturing Presence of Two Types of UHT Milk
}

\author{
Safae Tankiouine1, Hafida Zahir ${ }^{1}$, Mourad El Goulli' ${ }^{1}$, Kaoutar El Fazazi ${ }^{1,2}$, Abdelwahid Assaidi ${ }^{1}$, \\ Taoufik Hakim ${ }^{1}$, Mostafa El Louali ${ }^{1}$, Hassan Latrache ${ }^{{ }^{*}}$ \\ ${ }^{1}$ Laboratory of Bioprocess and Bio-Interface, Faculty of Science and Technics, Sultan Moulay Slimane University, Beni Mellal, \\ Morocco \\ ${ }^{2}$ Laboratory of Food Science and Technology, Qualipole Béni Mellal, Nationale Institute of Agricultural Research (INRA), Béni \\ Mellal, Morocco \\ Email: ^hafidazahir@yahoo.com
}

How to cite this paper: Tankiouine, S., Zahir, H., El Goulli, M., El Fazazi, K., Assaidi, A., Hakim, T., El Louali, M. and Latrache, H. (2020) Biocontamination Risk of Staphylococcus aureus in Dairy Manufacturing Presence of Two Types of UHT Milk. Food and Nutrition Sciences, 11, 824-835. https://doi.org/10.4236/fns.2020.118058

Received: June 18, 2020

Accepted: August 22, 2020

Published: August 25, 2020

Copyright $\odot 2020$ by author(s) and Scientific Research Publishing Inc. This work is licensed under the Creative Commons Attribution International License (CC BY 4.0).

http://creativecommons.org/licenses/by/4.0/ (c) (i) Open Access

\begin{abstract}
The biofilm formation on equipment surfaces in dairy manufacturing is a major concern for industry and consumers alike, which may affect the safety and quality of dairy products. In order to identify the bio-contamination risk of materials commonly used in dairy manufacturing, adhesion of Staphylococcus aureus on glass coated by two kinds of UHT milk (whole milk and skimmed milk) was investigated. It is known that adhesion is mainly governed by surface physicochemical properties, for that, the effect of milk components on physicochemical properties of glass and bacterial surfaces were exanimated through contact angle measurements. MATLAB software was used to evaluate the ability of $S$. aureus adhesion on glass. The hydrophobic quantitative and electron acceptor characteristics of the glass appear to increase with the presence of fat in milk, while its electron donor property decreases with this component. The percentage of occupied surface of untreated glass was more important than in treated surfaces for $50 \%$ of the strains studied. As well, the percentage of occupied surface by bacterial strains in untreated glass by skimmed milk is generally more important compared to the whole milk. Therefore, the risk of bio-contamination of untreated glass is more favorable for bacteria cultured in skimmed milk compared to these in whole milk but the bio-contamination risk on covered glass by milk is not milk dependent and is strain dependent.
\end{abstract}

\section{Keywords}

Physicochemical Properties, Skimmed UHT Milk, Whole UHT Milk, Contact Angle, Adhesion, Staphylococcus aureus 


\section{Introduction}

Every year, microbial contamination costs the food industry several millions of dollars, linked to significant losses of products that do not meet consumer expectations: degraded products containing an unacceptable number of contaminants in terms of both degradation and pathogenicity [1] [2]. In natural environments such as agro-food chains, microorganisms are most often attached to solid surface equipment with sufficient nutrients to ensure their survival and growth. These microorganisms, initially deposited on surfaces, adhere and actively multiply to form cell colonies. The adhesion of microorganisms is a phenomenon that depends on the involvement of three parameters: substrate, suspension medium, and bacterial cell [3]. Thus, to address these industrial problems, it was necessary to study, identify and characterize all the chemical and physico-chemical characteristics of the stakeholders involved in this phenomenon. Various bacteria produce toxins that cause food poisoning, resulting in symptoms ranging from gastrointestinal disorders to paralysis and death. Additionally, in the dairy industry, bio-adhesion poses serious problems such as the impedance of heat flow through steel surfaces (e.g. cooling and heating zones), the increase in the friction resistance of the liquid on the surface, as well as the increase in the corrosion rate of surfaces leading to energy losses [4]. Many studies have shown that fouling is initiated by the deposition of dairy constituents, mainly proteins and minerals, at the membrane surface specially during the filtration of dairy fluids [5]. Because once a material surface is exposed to an aqueous medium with nutrients, its interfacial proprieties are often modified by the surrounding fluid through the adsorption of organic compounds [6] [7] [8] [9] [10]. Since the interfacial properties are the result of physicochemical surfaces properties, it is very important to investigate the modification of that propriety by the presence of milk components to better understanding of bio-contamination phenomena, in dairy industry, and thus, propose solutions to eradicate or even avoid its appearance. Moreover, most of the research work has all cultivated the bacteria in laboratory culture media but in this work, the milk has been used as a culture medium for growth of six strains of Staphylococcus aureus of food origin,, and glass is used as a model in this work, and for the glass holder worked with two situations, treated and untreated with both types of UHT milk to assess the function and influence of lipid composition in the risk of contamination. These conditions should give us more realistic results than the laboratory medium.

\section{Materials and Methods}

\subsection{Bacterial Strains, Growth Conditions and Preparation of the Microbial Suspension}

Six bacterial strains of $S$. aureus isolated from raw milk were used in this study. The isolates were cultured in two types of milk UHT (skimmed and whole) for $24 \mathrm{~h}$ at $37^{\circ} \mathrm{C}$. Then, the cells were retrieved and washed twice using sterile dis- 
tilled water by centrifuged for 15 minutes at $8400 \mathrm{~g}$ and $37^{\circ} \mathrm{C}$, and suspended in a $\mathrm{KNO}_{3}$ for an ionic force of $0.1 \mathrm{M}$. The optical densities of each bacterial suspension were adjusted between 0.7 and 0.8 to have almost $10^{8} \mathrm{FCU} / \mathrm{ml}$.

\subsection{Cleaning of Glass Coupons}

The solid support selected for this study was the microscope slide glass (Knittel Glazer, Germany). The samples were divided into $1 \mathrm{~cm}^{2}$, before being covered with milk. The coupons were soaked for 15 minutes in a $70 \%$ ethanol solution $(\mathrm{Vol} / \mathrm{Vol})$ washed in distilled water and then sterilized in an autoclave at $120^{\circ} \mathrm{C}$ for 15 minutes. Glass was used as a model support.

\subsection{Treating Glass Coupons Using Milk}

The cleaned glass was placed in a Petri dish and $10 \mathrm{ml}$ of two types of milk were added: ultra-high temperature (UHT) treated milk and skimmed UHT milk. The glass was put in contact with the milk for 3 hours at $25^{\circ} \mathrm{C}$. After the contact time, the coupons in the glass were rinsed three times with distilled water.

\subsection{Contact Angle Measurements}

The hydrophobicity of glass coupons was determined by measuring the contact angle of water $(\theta \mathrm{w})$. The lifshitz van der Waals $\left(\gamma^{\mathrm{LW}}\right)$ component and the electron donor $(\gamma-)$ and electron acceptor $(\gamma+)$ surface energy parameters of glass coupons were determined by measuring contact angles using the approach proposed by Van Oss [11]. In this approach, in which spreading pressure is ignored, the contact angle $\theta$, measured with a pure liquid (L), is expressed as:

$$
\cos \theta=-1+2 \frac{\sqrt{\gamma_{\mathrm{S}}^{\mathrm{LW}}+} \sqrt{\gamma_{\mathrm{S}}^{+} \gamma_{\mathrm{L}}^{-}}+\sqrt{\gamma_{\mathrm{S}}^{-} \gamma_{\mathrm{L}}^{+}}}{\gamma_{\mathrm{L}}}
$$

Three liquids (one non-polar and two polar) are used. Thus, three equations are obtained which are solved to obtain $\gamma^{\mathrm{LW}}$ component and $\gamma^{-\mathrm{s}}$ and $\gamma^{\text {ts }}$ parameters for the solid substrate. The three pure liquids used were water (Milli-Q plus), formamide and diiodomethane.

The Lifshitz-van der Waals $\left(\gamma^{\mathrm{LW}}\right)$ component and the electron donor $(\gamma)$ and electron acceptor $\left(\gamma^{+}\right)$surface energy parameters of glass were found to be 31.97 , 46.24 and $1.14 \mathrm{mJm}^{-2}$, respectively.

Surface hydrophobicity was assessed by contact angle measurements and the van Oss approach [11] [12]. In this model, the level of hydrophobicity of a material is defined as the free energy of interaction between two elements of the material when it is submerged in water $(\mathrm{w}): \Delta \mathrm{G}_{\mathrm{iwi}}$. If the interactions between the two elements are greater than the interactions of each element and water, the element is hydrophobic. $\left(\Delta \mathrm{G}_{\mathrm{iwi}}<0\right)$; and vis versa for a hydrophilic material, $\Delta \mathrm{G}_{\mathrm{iwi}}>0$. According to the following formula, $\Delta \mathrm{G}_{\mathrm{iwi}}$ is calculated through the surface tensions of the interacting elements: 


$$
\begin{aligned}
& \Delta \mathrm{G}_{\mathrm{iwi}}=-2 \gamma_{\mathrm{iw}} \\
& =-2\left[\left(\left(\gamma_{\mathrm{i}}^{\mathrm{LW}}\right)^{\frac{1}{2}}-\left(\gamma_{\mathrm{w}}^{\mathrm{LW}}\right)^{\frac{1}{2}}\right)^{2}+2\left(\gamma_{\mathrm{i}}^{+} \gamma_{\mathrm{i}}^{-}\right)^{\frac{1}{2}}+\left(\gamma_{\mathrm{w}}^{+} \gamma_{\mathrm{w}}^{-}\right)^{\frac{1}{2}}-\left(\gamma_{\mathrm{i}}^{+} \gamma_{\mathrm{w}}^{-}\right)^{\frac{1}{2}}-\left(\gamma_{\mathrm{w}}^{+} \gamma_{\mathrm{i}}^{-}\right)^{\frac{1}{2}}\right]
\end{aligned}
$$

\subsection{Adhesion Experiments}

Ten millimeters of bacterial suspension containing 108CFU ml1 was incubated in a Petri dish containing a glass coupon treated with milk (whole, skimmed) for $3 \mathrm{~h}$ at $25^{\circ} \mathrm{C}$. After incubation for $3 \mathrm{~h}$ at $25^{\circ} \mathrm{C}$, the coupons were then rinsed three times with sterilized distilled water to remove non-adherent bacteria.

\subsection{Quantification of the Adhesion of Microorganisms by Matlab Software}

The quantification of the adhesion is carried out using a program developed on Matlab v.7.1 software by the research team Laboratory of Bioprocess and Bio-interfaces at the faculty of Sciences and Techniques of Beni Mellal [13].

The obtained microscopic images are converted into images of 256 gray levels and are processed in order to establish a histogram representing the number of pixels according to their intensity. In such treatment, the intensity 0 is attributed to a black pixel, whereas a white pixel corresponds to the intensity 255 . The zones corresponding to the colonization of the microorganisms are easily detected with respect to the original image.

\subsection{Statistical Analysis}

The statistical analyses were performed using software STATISTICA version 6 . The Newman-keuls test was used to compare the means $\log 10 \mathrm{UFC} / \mathrm{cm}^{2}$ of each surface before and after treatment $(\mathrm{P}<0.05)$. The means presented in the figures with the same letters are not significantly different and those with different letters are significantly different.

\section{Results and Discussion}

\subsection{Influence of Milk Conditioning Film on the Physicochemical Properties of Glass}

In the agri-food environment, materials surface is quickly covered with an organic conditioning film [7], this film can occur within seconds of exposure to an aqueous environment [14]. On dairy industry, this film could be composed of different milk components [14].

Table 1 presents the surface physicochemical characteristics of glass before treatment with the two types of milk. The contact angle with water can be used as a qualitative indication of the cell surface hydrophobicity [15]. Based on the approach of van Oss [16], it is possible to determine the absolute degree of hydrophobicity of any substance towards water (w), which can be accurately expressed in the internationally applicable system of units. The glass surface was 
Table 1. Surface tension components and free energy interaction of glass treated and untreated with various milks.

\begin{tabular}{|c|c|c|c|c|c|c|c|}
\hline \multirow{2}{*}{ Milk } & \multicolumn{3}{|c|}{ Contact angle $\left(^{\circ}\right)$} & \multicolumn{4}{|c|}{$\begin{array}{l}\text { Surface free energy } \\
\text { components }\left(\mathrm{mJm}^{-2}\right)\end{array}$} \\
\hline & Diiodomethane & Formamide & Water & $\gamma^{\mathrm{LW}}$ & $\gamma^{-}$ & $\gamma^{+}$ & $\Delta \mathrm{G}_{\mathrm{iWi}}$ \\
\hline Untreated & $\begin{array}{l}46.4 \\
(1.2)\end{array}$ & $\begin{array}{l}45.8 \\
(1.6)\end{array}$ & $\begin{array}{l}36.5 \\
(1.0)\end{array}$ & $\begin{array}{l}36.3 \\
(1.3)\end{array}$ & $\begin{array}{c}54 \\
(1.5)\end{array}$ & $\begin{array}{c}00 \\
(1.2)\end{array}$ & $\begin{array}{l}42.74 \\
(1.3)\end{array}$ \\
\hline $\begin{array}{l}\text { Glass skimmed } \\
\text { milk }\end{array}$ & $\begin{array}{l}63.9 \\
(1.5)\end{array}$ & $\begin{array}{l}70.7 \\
(1.2)\end{array}$ & $\begin{array}{l}82.1 \\
(1.3)\end{array}$ & $\begin{array}{l}26.3 \\
(1.2)\end{array}$ & $\begin{array}{c}0.1 \\
(1.23)\end{array}$ & $\begin{array}{c}10.1 \\
(1.39)\end{array}$ & $\begin{array}{l}-35.6 \\
(1.44)\end{array}$ \\
\hline $\begin{array}{l}\text { Glass whole } \\
\text { milk }\end{array}$ & $\begin{array}{l}54.7 \\
(1.7)\end{array}$ & $\begin{array}{l}89.7 \\
(2.1)\end{array}$ & $\begin{array}{l}95.1 \\
(2.2)\end{array}$ & $\begin{array}{l}95.6 \\
(1.9)\end{array}$ & $\begin{array}{c}9.3 \\
(2.23)\end{array}$ & $\begin{array}{c}2.8 \\
(1.89)\end{array}$ & $\begin{array}{r}-28.69 \\
(2.35)\end{array}$ \\
\hline
\end{tabular}

$\gamma^{\mathrm{LW}}$ : The Lifshitz-Van der Waals components of the surface tension. $\gamma$ : electron donor components of the surface tension. $\gamma^{+}$: electron acceptor components of the surface tension. $\Delta \mathrm{G}_{\mathrm{iwi}}$ : the free energy of interaction between two entities of that material when immersed in water.

hydrophilic $\left(\Delta \mathrm{G}_{\mathrm{iwi}}>0\right)$ and predominantly highly electron donor with a low electrons acceptor character.

The surface tension values have been measured after treatment of the surface with two types of milk at $25^{\circ} \mathrm{C}$. The results are presented in Table 1. A large change of physicochemical properties was observed regardless. Important variations in electron donor were detected after contact of the glass with the two types of milk. Regardless of the treatment conditions, the electron donor for the glass decreases after treatment by more than $90 \%$. The difference in character of the electron donor after treatment with the two types of milk gives the following results: the value of the donor character after treatment with UHT milk decreases, on the other hand, the value of the acceptor character increases. Then the level of these changes depends on the type of milk used for treatment.

\subsection{Influence of Types of Milk Conditioning Film on the Physico-Chemical Properties of Glass}

The results also show that the glass surface changes its physicochemical properties. This could be due to the nature of the culture medium. The results also show that the glass surface quantitative hydrophobicity increase after treatment with a different milk. After treatment, the glass quantitative hydrophobicity increases with the augmented presence of the fat components. Finally, we can suggest that there is a parallelism between the presence of fat components of milk, electrons donor character and quantitative hydrophobicity of glass. The parameters increase in the presence of milk, particularly for skimmed milk where the $\Delta \mathrm{G}_{\text {iwi }}$ pass from (42.74) to (-35.6). Several works have shown that the hydrophobicity measured by the contact angle, is directly correlated with the high ratio of N/C concentrations and inversely correlated with $\mathrm{O} / \mathrm{C}$ concentrations [17]-[25]. 


\subsection{Influence of Different Types of Milk on Adhesion of}

\section{S. aureus}

We have evaluated the risk of biocontamination of two different situations of glass treated with skimmed and whole milk for $3 \mathrm{~h}$. The results of adhesion of the six $S$. aureus strains cultured in milk on untreated and treated glass show differences in terms of the degree of bacteria attachment to glass supports.

The adhesion of six $S$. aureus cultivated in skimmed milk on the untreated glass shows a better adhesion of the bacteria for all strains except the number 2 (Figure 1 and Figure 2). The results show that six strains of $S$. aureus adhere easily to a clean (untreated) substrate. These results are in agreement with those obtained by other authors [13] [26] [27] [28]. The results of the untreated glass test showed that when strains $1,3,4,5$ and 6 (except the strain 2) were grown in skimmed milk, the adhesion was high, with values of the occupied surface respectively of $7.33 \%, 19.21 \%, 26.09 \%, 17.07 \%$ and $11.54 \%$. However, bacteria grown in whole milk with a percentage of the occupied surface area of $(4.59 \%)$, (2.77\%), (8.5\%), (4.95\%) and (2.89\%) for strains 1, 3, 4, 5 and 6 respectively (Figure 2). In addition, an ANOVA statistical analysis showed that the type of milk (skim or whole) had a large effect on the adhesion of $S$. aureus on untreated glass coupons $(0.05>\mathrm{P})$. However, when glass coupons were treated with milk (skim or whole); did not affect the adhesion of $S$. aureus $(0.05<\mathrm{P})$. Numerous studies have shown that $S$. aureus adheres in different to untreated surfaces such as stainless steel [13] [26] [28].

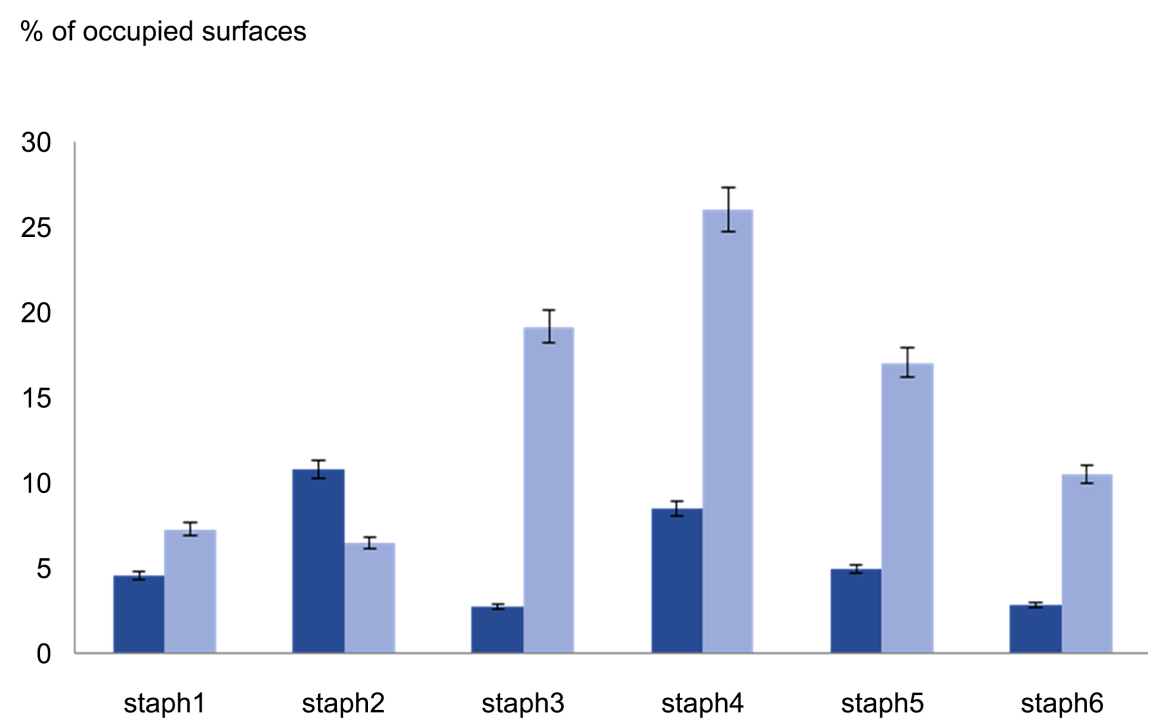

S.aureus grown in whole milk

S.aureus grown in skimmed milk

Figure 1. Adhesion of Staphylococcus aureus cultivated in two types of milk on untreated glass. 


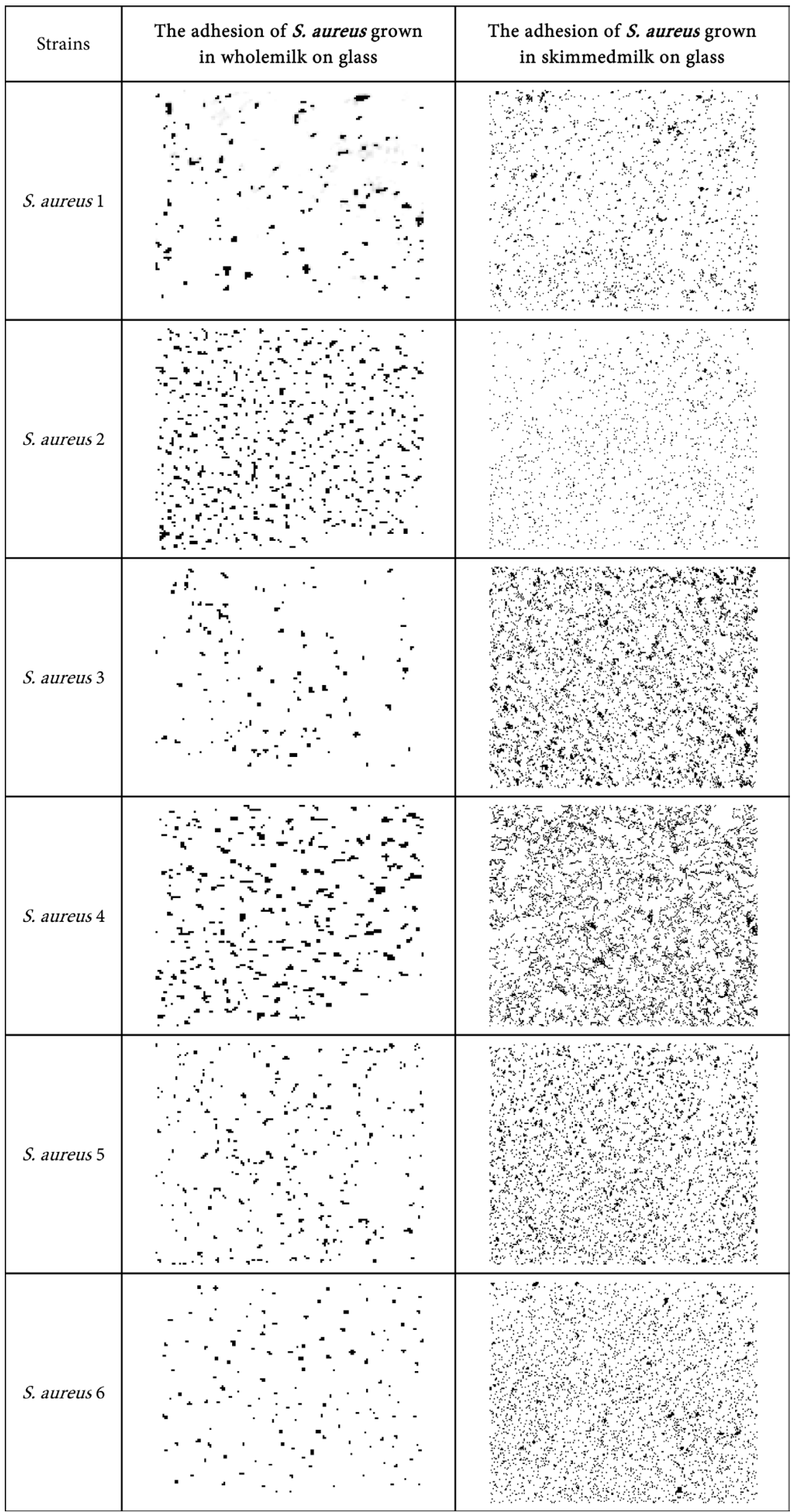

Figure 2. MATLAB images of $S$. aureus adhesion on untreated glass $(\mathrm{G} \times 400)$. 
In the case of glass surfaces treated with milk, it should be noted that the bacteria do not adhere in the same way as the case of treated surface with skimmed milk. The percentage of surface occupied decreases for all strains except forstaph 1 and 2. In addition, for the surface treated with whole milk the percentage of surface occupied increases for staph 1, 2 and 3 and almost no change for staph 4, 5 and 6 . The strains are not always the same level of attachment on the glass (Figure 3 and Figure 4) with those reported by Barnes, Lo [29] who observed that the preconditioning of stainless steel surface with milk or individual milk proteins reduced the adhesion of Staphylococcus aureus, Pseudomonas fragi, Escherichia coli, Listeria monocytogenes, and Serratia marcescens to stainless steel after $2 \mathrm{~h}$ of incubation.

\section{Conclusions}

The physico-chemistry of solid surfaces is influenced by the nature of foodstuffs and their compounds in terms of the risk of biocontamination in the dairy industry.

In conclusion, these results show that the nature, the packaging of the surfaces and also the food product must be taken into account throughout the manufacturing chain to avoid bio-contamination of the products and also to control the cleaning and disinfection procedures of the different materials used in the manufacture of dairy and food products.

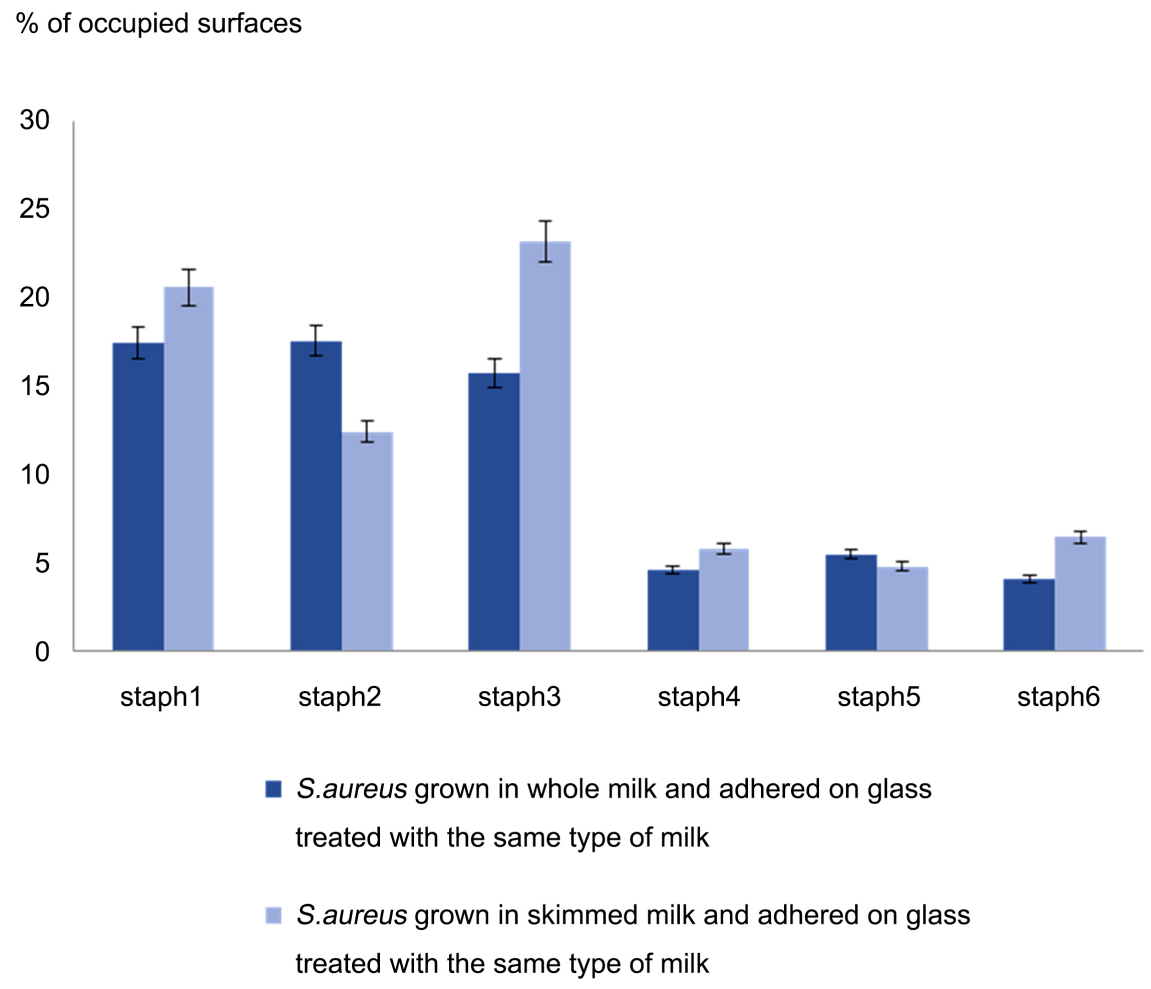

Figure 3. Adhesion of six grown Staphylococcus aureus strains in two types of milk on glass treated with the same types of milk. 


\begin{tabular}{|c|c|c|}
\hline & $\begin{array}{l}\text { The adhesion of } S \text {. aureus } \text { grown } \\
\text { in whole milk on glass treated } \\
\text { with the same type of milk }\end{array}$ & $\begin{array}{l}\text { The adhesion of } S \text {. aureus grown } \\
\text { in skimmed milk on glass treated } \\
\text { with the same type of milk }\end{array}$ \\
\hline S. aureus 1 & 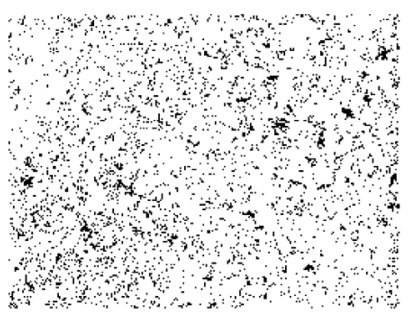 & 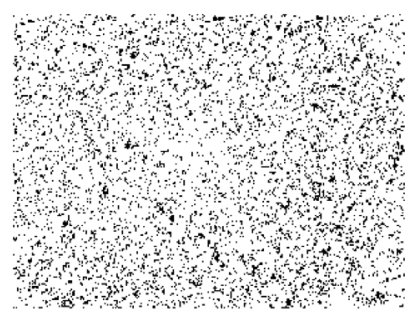 \\
\hline$S$. aureus 2 & 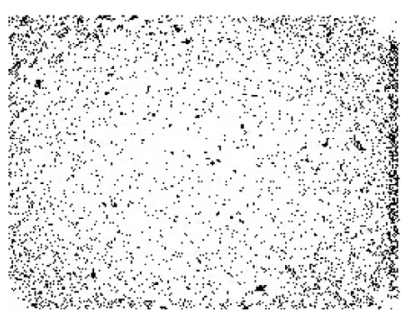 & 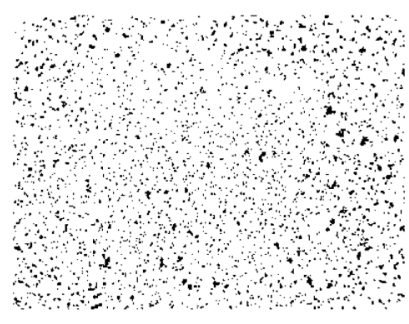 \\
\hline$S$. aureus 3 & 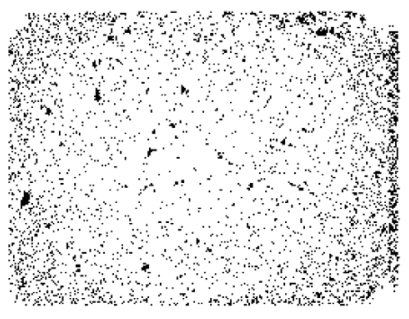 & $\begin{array}{lll}m \\
m\end{array}$ \\
\hline$S$. aureus 4 & 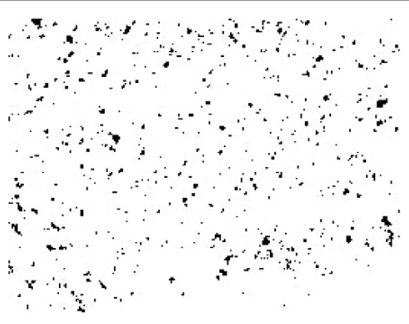 & 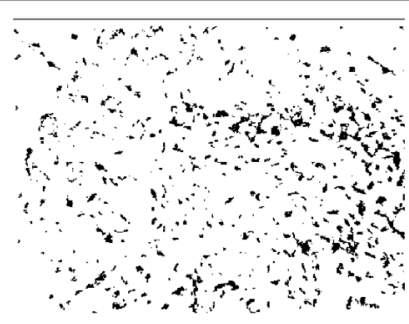 \\
\hline$S$. aureus 5 & 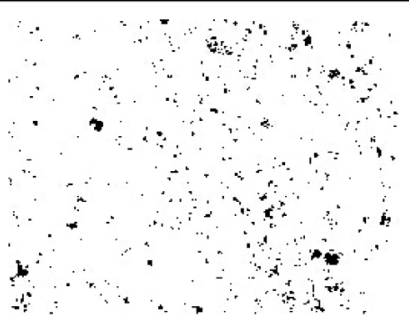 & 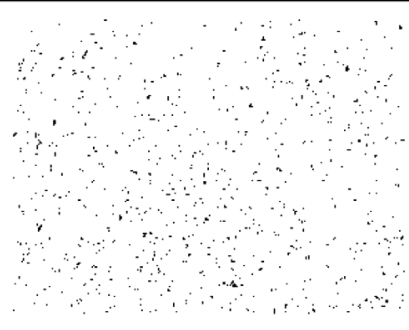 \\
\hline$S$. aureus 6 & 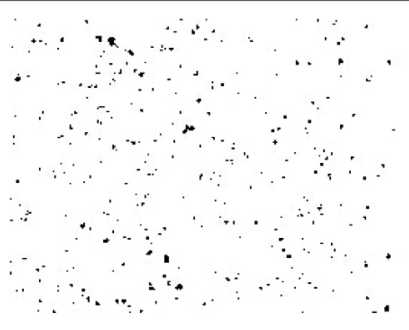 & a \\
\hline
\end{tabular}

Figure 4. MATLAB-treated images of $S$. aureus adhesion on treated glass with two types of UHT milk $(\mathrm{G} \times 400)$. 


\section{Conflicts of Interest}

The authors declare no conflicts of interest regarding the publication of this paper.

\section{References}

[1] Hussain, M.A. and Dawson C.O. (2013) Economic Impact of Food Safety Outbreaks on Food Businesses. Foods, 2, 585-589. https://doi.org/10.3390/foods2040585

[2] Mead, G. (2004) Microbiological Quality of Poultry Meat: A Review. Brazilian Journal of Poultry Science, 6, 135-142. https://doi.org/10.1590/S1516-635X2004000300001

[3] Garrett, T.R., Bhakoo, M. and Zhang, Z. (2008) Bacterial Adhesion and Biofilms on Surfaces. Progress in Natural Science, 18, 1049-1056. https://doi.org/10.1016/j.pnsc.2008.04.001

[4] Teh, K.H., Flint, S., Brooks, J. and Knight, G. (2015) Biofilms in the Dairy Industry. John Wiley \& Sons, Hoboken. https://doi.org/10.1002/9781118876282

[5] James, B.J., Jing, Y. and Chen, X.D. (2003) Membrane Fouling during Filtration of Milk-A Microstructural Study. Journal of Food Engineering, 60, 431-437. https://doi.org/10.1016/S0260-8774(03)00066-9

[6] Shakeri Fard, P. (2010) Production and Purification of Biosurfactants and Study of Their Influence on Surface Properties of Stainless Steel and Teflon. University of Lille 1, Lille.

[7] Chmielewski, R.A.N. and Frank, J.F. (2003) Biofilm Formation and Control in Food Processing Facilities. Comprehensive Reviews in Food Science and Food Safety, 2, 22-32. https://doi.org/10.1111/j.1541-4337.2003.tb00012.x

[8] Boswell, T.C., Marshall, L.E. and Kudesia, G. (1996) False-Positive Legionella Titres in Routine Clinical Serology Testing Detected by Absorption with Campylobacter: Implications for the Serological Diagnosis of Legionnaires' Disease. The Journal of Infection, 32, 23-26. https://doi.org/10.1016/S0163-4453(96)80005-3

[9] Sheng, X., Ting, Y.P. and Pehkonen, S.O. (2008) The Influence of Ionic Strength, Nutrients and $\mathrm{pH}$ on Bacterial Adhesion to Metals. Journal of Colloid and Interface Science, 321, 256-264. https://doi.org/10.1016/j.jcis.2008.02.038

[10] Somers, E.B. and Lee Wong, A.C. (2004) Efficacy of Two Cleaning and Sanitizing Combinations on Listeria monocytogenes Biofilms Formed at Low Temperature on a Variety of Materials in the Presence of Ready-to-Eat Meat Residue. Journal of Food Protection, 67, 2218-2229. https://doi.org/10.4315/0362-028X-67.10.2218

[11] Van Oss, C.J. (1995) Hydrophobicity of Biosurfaces-Origin, Quantitative Determination and Interaction Energies. Colloids and Surfaces B: Biointerfaces, 5, 91-110. https://doi.org/10.1016/0927-7765(95)01217-7

[12] Van Oss, C.J., Good, R.J. and Chaudhury, M.K. (1988) Additive and Nonadditive Surface Tension Components and the Interpretation of Contact Angles. Langmuir, 4, 884-891. https://doi.org/10.1021/la00082a018

[13] Hamadi, F., Latrache, H., Mabrrouki, M., Elghmari, A., Outzourhit, A., Ellouali, M. and Chtaini, A. (2005) Effect of $\mathrm{pH}$ on Distribution and Adhesion of Staphylococcus Aureus to Glass. Journal of Adhesion Science and Technology, 19, 73-85. https://doi.org/10.1163/1568561053066891

[14] Mittelman, M.W. (1998) Structure and Functional Characteristics of Bacterial Biofilms in Fluid Processing Operations. Journal of Dairy Science, 81, 2760-2764. 
https://doi.org/10.3168/jds.S0022-0302(98)75833-3

[15] Oliveira, R., Azeredo, J., Teixeira, P. and Fonseca, A.P. (2001) The Role of Hydrophobicity in Bacterial Adhesion.

[16] Van Oss, C.J. (1997) Hydrophobicity and Hydrophilicity of Biosurfaces. Current Opinion in Colloid \& Interface Science, 2, 503-512. https://doi.org/10.1016/S1359-0294(97)80099-4

[17] Cowan, M.M., Van Der Mei, H.C., Rouxhet, P.G. and Busscher, H.J. (1992) Physico-Chemical and Structural Properties of the Surfaces of Peptostreptococcus micros and Streptococcus mitis as Compared to Those of Mutans Streptococci, Streptococcus sanguis and Streptococcus salivarius. Microbiology Society, 138, 2707-2714. https://doi.org/10.1099/00221287-138-12-2707

[18] Mozes, N., Amory, D.E., Léonard, A.J. and Rouxcet, P.G. (1989) Surface Properties of Microbial Cells and Their Role in Adhesion and Flocculation. Colloids and Surfaces, 42, 313-329. https://doi.org/10.1016/0166-6622(89)80199-4

[19] Cuperus, P.L., Van Der Mei, H.C., Reid, G., Bruce, A.W., Khoury, A.H., Rouxhet, P.G. and Busscher, H.J. (1993) Physicochemical Surface Characteristics of Urogenital and Poultry Lactobacilli. Journal of Colloid and Interface Science, 156, 319-324. https://doi.org/10.1006/jcis.1993.1118

[20] Latrache, H., Mozes, N., Pelletier, C. and Bourlioux, P. (1994) Chemical and Physicochemical Properties of Escherichia coli: Variations among Three Strains and Influence of Culture Conditions. Colloids and Surfaces B: Biointerfaces, 2, 47-56. https://doi.org/10.1016/0927-7765(94)80017-0

[21] Van Der Mei, H.C. and Busscher, H.J. (1997) The Use of X-Ray Photoelectron Spectroscopy for the Study of Oral Streptococcal Cell Surfaces. Advances in Dental Research, 11, 388-394. https://doi.org/10.1177/08959374970110040301

[22] Dengis, P.B. and Rouxhet P.G. (1997) Surface Properties of Top- and Bottom-Fermenting Yeast. Yeast, 13, 931-943.

https://doi.org/10.1002/(SICI)1097-0061(199708)13:10\%3C931::AID-YEA149\%3E3. $\underline{0 . C O ; 2-T}$

[23] Dufrêne, Y.F., Van Der Wal, A., Norde, W. and Rouxhet, P.G. (1997) X-Ray Photoelectron Spectroscopy Analysis of Whole Cells and Isolated Cell Walls of Gram-Positive Bacteria: Comparison with Biochemical Analysis. Journal of Bacteriology, 179, 1023-1028. https://doi.org/10.1128/JB.179.4.1023-1028.1997

[24] Boonaert, C.J. and Rouxhet, P.G. (2000) Surface of Lactic Acid Bacteria: Relationships between Chemical Composition and Physicochemical Properties. Applied and Environmental Microbiology, 66, 2548-2554. https://doi.org/10.1128/AEM.66.6.2548-2554.2000

[25] Latrache, H., El, G., Karroua, M., Hakkou, A., Ait, M.H., El, B.A. and Bourlioux, P. (2002) Relations between Hydrophobicity Tested by Three Methods and Surface Chemical Composition of Escherichia coli. The New Microbiologica, 25, 75-82.

[26] Oulahal, N., Brice, W., Martial, A. and Degraeve, P. (2008) Quantitative Analysis of Survival of Staphylococcus aureus or Listeria innocua on Two Types of Surfaces: Polypropylene and Stainless Steel in Contact with Three Different Dairy Products. Food Control, 19, 178-185. https://doi.org/10.1016/j.foodcont.2007.03.006

[27] Herrera, J.J.R., Cabo, M.L., González, A., Pazos, I. and Pastoriza, L. (2007) Adhesion and Detachment Kinetics of Several Strains of Staphylococcus aureus subsp. aureus under Three Different Experimental Conditions. Food Microbiology, 24, 585-591. https://doi.org/10.1016/j.fm.2007.01.001

[28] Marques, S.C., Oliveira Silva Rezende, J.D.G., De Freitas Alves, L.A., Silva, B.C., 
Alves, E., De Abreu, L.R. and Piccoli, R.H. (2007) Formation of Biofilms by Staphylococcus aureus on Stainless Steel and Glass Surfaces and Its Resistance to Some Selected Chemical Sanitizers. Brazilian Journal of Microbiology, 38, 538-543.

https://doi.org/10.1590/S1517-83822007000300029

[29] Barnes, L.-M., Lo, M.F., Adams, M.R. and Chamberlain, A.H.L. (1999) Effect of Milk Proteins on Adhesion of Bacteria to Stainless Steel Surfaces. Applied and Environmental Microbiology, 65, 4543-4548.

https://doi.org/10.1128/AEM.65.10.4543-4548.1999 